\title{
FORAGE YIELD AND PROTEIN CONTENT OF DIFFERENT FIELD PEA CULTIVARS AND OAT MIXTURES GROWN AS WINTER CROPS
}

\author{
Ivan KRGA ${ }^{1 *}$, Aleksandar SIMIĆ ${ }^{2}$,Violeta MANDIĆ ${ }^{3}$,Zorica BIJELIĆ ${ }^{3}$ Željko DŽELETOVIĆ ${ }^{4}$, Sanja \\ VASILJEVIĆ ${ }^{5}$ Slađan ADŽIĆ ${ }^{l}$ \\ ${ }^{1}$ Institute for Vegetable Crops, Karadjordjeva, Smederevska Palanka, SERBIA \\ ${ }^{2}$ University of Belgrade, Faculty of Agriculture, Nemanjina, Belgrade, SERBIA \\ ${ }^{3}$ Institute for Animal Husbandry, Autoput, Belgrade, SERBIA \\ ${ }^{4}$ University of Belgrade, Institute for Application for Nuclear Energy-INEP, Banatska, Zemun, Belgrade, \\ SERBIA \\ ${ }^{5}$ Institute for Field and Vegetable Crops, Maksima Gorkog, Novi Sad, SERBIA \\ *Corresponding author: ivan.krga@yahoo.com
}

Received: 05.05.2019

\begin{abstract}
Monoculture and intensive use of mechanization and inorganic chemicals are leading to degradation and erosion of our soils and agro-ecosystems. At the same time, the production of animal feeds that are rich in protein is constantly decreasing in many European countries. Modest cultivation needs, favorable content of nutrients, and beneficial effect on the environment, make field pea and oat mixtures promising crops to tackle these issues. In three growing seasons and without irrigation or fertilisation, we have examined two basic field pea cultivars (Kosmaj, OS Adam) and one leafless cultivar (OS Letin) intercropped with oat (NS Jadar), with seeding rates, field pea: oat $-100: 10 \% ; 100: 20 \%$. Results have shown that basic type cultivars have better overall development and higher yields compared to leafless cultivar, whether grown as single crops or in the mixture. Basic cultivars (OS Adam, Kosmaj) achieved higher protein content, compared to cultivar Letin, $163.9 \mathrm{~g} \mathrm{~kg}^{-1}, 153.3 \mathrm{~g} \mathrm{~kg}^{-1}, 136 \mathrm{~g} \mathrm{~kg}^{-1}$, respectively. Yields were higher in 100:20\% mixtures, compared to 100:10\% mixtures and single grown crops, and we conclude that intercropping these species is superior to cultivating them separately. Protein content wasn't significantly different between two seeding rates, thus seed rates shouldn't be lower than 100:20\%.
\end{abstract}

Keywords: Biomass, cereals, intercropping, legumes, mixture, productivity

\section{INTRODUCTION}

The need to provide quality feeds rich in protein for animal feeding is increasingly challenging. In Europe, for example, most of the proteins that are required in animal feeding are satisfied by importing the soybean and its products (Borreani et al., 2006; Henseler et al., 2013). At the same time, modern agriculture with the increased use of agrochemicals, mechanization, and monoculture practices have led to a degradation of agro-ecosystems and the environment (Lithourgidis et al., 2011). One way to cover the need for proteins and to reduce the negative aspects of modern agriculture is by producing quality forage that is based on legume and grass/cereal mixtures. Growing these mixtures is beneficial for the environment, sustainable agriculture and can decrease the dependence on import and relieve the financial burden from the farmers.

Benefits of growing legume species with grasses or cereals for forage production are reflected in an increased yield when compared to individually grown crops (Sukhdev, 2012; Rauber et al., 2001), better and more balanced quality of feed (Chapko et al., 2013), better influence on the soil due to nitrogen fixation (HauggaardNielsen et al., 2001, Hauggaard-Nielsen et al., 2009), more balanced nutrient uptake from the soil (Li et al., 2001), soil moisture and solar radiation (Coll et al., 2012), reduced damage caused by the diseases (Živanov et al., 2014), insects and weeds (Banik et al., 2006; Sekamatte et al., 2003), reduced lodging, etc. Differences between intercropped and individually grown crops are notably manifested in poorer soils and in scarce growing conditions (Hauggaard-Nielsen et al., 2009). It should be noted that legume silage is hard to obtain due to its lower carbohydrate content and the presence of other substances that hinder the process of ensiling. Combining legumes with grass or cereal species would highly facilitate this process since Poaceae are rich in carbohydrates and other fermentable substances. Growing legume-grass mixtures has some challenges. These challenges are reflected in the 
lack of appropriate mechanization since available mechanization is, mostly oriented toward the single crop cultivation. The protection from weeds could be a problem since herbicides for mixed species are almost nonexistent. However, research has shown that intercropped species such as field pea with cereals are better with suppressing the weeds compared to single grown crops (Gronle et al., 2014; Deveikyte et al., 2009; Poggio, 2005).

Field pea (Pisum sativum ssp. arvense) for forage is the most commonly used species for intercropping with cereals (Chapagain and Riseman, 2014). As any other legume it has ecological significance since it enriches the soil with nitrogen. Therefore the need for nitrogen fertilizers is significantly reduced compared to other field crops. Field pea has good resistance to extremely low temperatures, and seedlings can survive up to a $-20{ }^{\circ} \mathrm{C}$ (Shereena and Salim, 2006) or even more (Prusinski, 2016). This makes field pea perfect crop for cool European winters when the soils are mostly without crops and are exposed to winds and erosion.

Growing field pea and oat in a mixture is beneficial since both species are relatively tolerant to the limited growing conditions and a wider range of soil $\mathrm{pH}$. In subtropical and continental climate, species whose vegetation ends before the arrival of summer droughts and high temperatures have priority and are more reliable for cultivation. This includes field pea and oat when grown for forage. The cultivation season for forage is short, and these crops are ready for harvest relatively quickly (approximately 2 months) after seeding. After their harvest, there is a sufficient period of favourable growing conditions for the cultivation of catch crops. Field pea is highly prone to lodging under strong winds and rains, and oat comes as a perfect supporting crop to reduce this phenomenon.

The aim of this study was to examine the potential of field pea and oat in limited, dry growing conditions and to find an environment-friendly and sustainable alternative to the currently grown monoculture species. Specific objects of this study were to examine the most suitable seeding rates, as well as examining whether leafless or basic type cultivars provide better results in these and similar growing conditions.

\section{MATERIALS and METHODS}

\section{Site description}

The field trials were conducted on calcareous chernozem soil at the Institute for Animal Husbandry (4450'18,9" N; 20¹7'0,6" E, elevation $66 \mathrm{~m}$ ), Belgrade, Serbia, during three seasons (winters), 2015/2016, $2016 / 2017,2017 / 2018$. Tillage has been carried out to a depth of $25 \mathrm{~cm}$, and the seedbed preparation to a $5 \mathrm{~cm}$ depth before sowing. Crops were grown without previous fertilization and irrigation.

\section{Soil parameters and meteorological conditions}

The following chemical parameters were determined for non-calcareous chernozem soil (IUSS Working Group WRB, 2014) in the laboratory: $\mathrm{pH}$ in $\mathrm{KCl} \mathrm{5.61,} \mathrm{2.65 \%}$ organic matter, $0.1 \%$ total $\mathrm{N}$ by Bremner method (1996), available forms P2O5 $2.49 \mathrm{mg} 100 \mathrm{~g}^{-1}$ soil and $\mathrm{K} 2 \mathrm{O} 16.07$ mg $100 \mathrm{~g}^{-1}$ soil (determined using the standard ALmethod, Egner et al., 1960).

The region in which the trials were conducted is characterized by a moderate winter and moderate spring conditions (Table 1), with occasional extremely low temperatures (sometimes $-20{ }^{\circ} \mathrm{C}$ ).

Table 1. Monthly precipitations and average temperatures, Meteorological Yearbook of Serbia - region of Belgrade.

\begin{tabular}{cccccc}
\hline & \multicolumn{5}{c}{ Months } \\
\cline { 2 - 5 } Year & I & II & III & IV & Sum \\
\cline { 2 - 5 } & \multicolumn{5}{c}{ Monthly precipitations (mm) } \\
\hline $81^{\prime}-10^{\prime}$ & 46.9 & 40.0 & 49.3 & 56.1 & 192.3 \\
2016 & 46.3 & 38.5 & 102.6 & 53.9 & 241.3 \\
2017 & 23.4 & 23.5 & 27 & 51.8 & 125.7 \\
2018 & 33.9 & 54.2 & 68.7 & 21.5 & 178.3 \\
\hline $81^{\prime}-10{ }^{\prime}$ & 1.4 & Average monthly temperatures $\left({ }^{\circ} \mathbf{C}\right)$ & 12.9 & Average \\
2016 & 2.5 & 3.1 & 7.6 & 15.5 & 9.25 \\
2017 & 3.3 & 9.0 & 9.1 & 12.7 & 8.22 \\
2018 & 4.5 & 5.4 & 11.5 & 17 & 7.32 \\
\hline
\end{tabular}

81 '-10' - reference period (1981-2010)

\section{Experimental design}

A two-factorial experiment was set at the beginning of November and harvested in the full flowering stage of field pea and milk stage of oat, throughout May. The first factor was field pea cultivars, two basic types (Kosmaj and OS-Adam), one leafless type (OS-Letin) grown in mixture with an oat cultivar (NS-Jadar). The second factor was additive sowing design, mixture 100:10\% and mixture 100:20\% (field pea: oat). The experimental design was a randomized block design with three replications and subplot area $8 \mathrm{~m}^{2}$. The seed rate was $150 \mathrm{~kg} \mathrm{ha}^{-1}$ for $\mathrm{cv}$. Kosmaj, cv. Letin and cv. NS-Jadar, and $120 \mathrm{~kg} \mathrm{ha}^{-1}$ for the cv. Adam (this was to achieve the same number of plants per ha ${ }^{-1}$, since cv. Adam has smaller seeds). 


\section{Forage and plant measurements}

Plant height, number of internodes, fresh and dry weight yield, the share of two species in yield, LER (Land Equivalent Ratio) and protein content was determined. The plant height and number of internodes were measured on 30 random plants from each subplot. Forage mass was measured for each subplot area, and then $1 \mathrm{~kg}$ of mass was dried on $65{ }^{\circ} \mathrm{C}$ during 24 hours period. The share of pea and oat in yield was determined by sampling $1 \mathrm{~m}^{2}$ of each subplot, separating and measuring the mass of two species. The crude protein content was determined using the Kjeldahl method (AOAC, 2000). LER (Land Equivalent Ratio) was calculated by the formula:

LER $=Y_{F}$ in mixture $/ Y_{F}$ in single grown crop $+Y_{O}$ in mixture / $\mathrm{Y}_{\mathrm{O}}$ in single grown crop

$$
\begin{aligned}
& Y_{F}=\text { yield of field pea } \\
& Y_{O}=\text { yield of oat }
\end{aligned}
$$

When the LER index is higher than 1, the mixture has higher yields on the same plot area as the single grown crops. When the LER index is lower than 1, the mixture has lower yields on the same plot area as the single grown crops (Mead and Willey, 1980).

\section{Statistical methods}

Statistical analysis was performed using Statistika 8.0 software. Results were analyzed for normal distribution, followed by two-factorial ANOVA. The test of significance was calculated by using the Fisher LSD test, $p<0.05$ and $p<0.01$. Analyzed results are presented in the tables and figures.

\section{RESULTS and DISCUSSION}

Natural fertility of the soil on which the crops were grown was average to low. Crops were uniform and we couldn't detect any signs of nutrient deficiency or pest damage. Highest precipitations and temperatures were recorded in the first experimental year. The lowest levels of rainfall were recorded in the second year.

Plant height and the number of internodes indicate the overall development of the plants. The height of plants could be beneficial for the species in mixture due to their mutual competition for sun. This trait is not as favorable when field pea is grown as single crop due to its tendency for lodging. The number of internodes is especially important since this is closely related to the number of leaves, photosynthetic ability, etc.

The highest plants were observed for the cv. Kosmaj, followed by the cv. Adam, while the cv. Letin had the shortest plants (table 2). The highest number of internodes was recorded for the cv. Adam and Kosmaj and lowest for the cv. Letin. For comparison, mean values for plant height and the number of internodes for cv. Letin, examined on another location (Krizmanić et al., 2017), were $115 \mathrm{~cm}$ for height and 18 for the number of internodes, which is significantly higher compared to the values in this trial. In the same trial, average values for plant height and number of internodes, for 13 different cultivars and lines are as follows, plant height for 2012. $97 \mathrm{~cm}, 2013$. - $126 \mathrm{~cm}$ on average, number of internodes for 2012. - 17 and 2013. - 19 on average. Plant height for cv. Kosmaj was similar to the mentioned values, while the number of internodes for all examined cultivars were lower. Cultivation of Letin in the region of central Serbia showed significantly lower values compared to two other cultivars, and Letin examined on another location (Krizmanić et al., 2017). The overall performance of this cultivar is not that stable in these growing conditions, while basic type cultivars showed satisfactory results. Field pea share in yield had significant variations only in the second year, and it was highest for cultivar Kosmaj.

Table 2. Plant height, number of internodes and yield share for different field pea cultivars intercropped with oat.

\begin{tabular}{cccccccccc}
\hline & \multicolumn{3}{c}{ Plant height $(\mathbf{c m})$} & \multicolumn{3}{c}{ Number of internodes } & \multicolumn{3}{c}{ Field pea share in yield (\%) } \\
\hline Cultivar & I & II & III & I & II & III & I & II & III \\
\hline Kosmaj & $136.1^{\mathrm{a}}$ & $124.3^{\mathrm{a}}$ & $104^{\mathrm{a}}$ & $16.2^{\mathrm{a}}$ & $13.5^{\mathrm{a}}$ & $12.5^{\mathrm{b}}$ & 88.5 & $96.55^{\mathrm{a}}$ & 62.3 \\
Adam & $104.3^{\mathrm{b}}$ & $95.1^{\mathrm{b}}$ & $89.9^{\mathrm{b}}$ & $12.7^{\mathrm{b}}$ & $13.3^{\mathrm{a}}$ & $13.3^{\mathrm{a}}$ & 90.05 & $88.68^{\mathrm{b}}$ & 64.17 \\
Letin & $78.9^{\mathrm{c}}$ & $85.1^{\mathrm{c}}$ & $92.5^{\mathrm{b}}$ & $11.7^{\mathrm{b}}$ & $11.8^{\mathrm{b}}$ & $11.4^{\mathrm{c}}$ & 91.37 & $88.22^{\mathrm{b}}$ & 58.31 \\
F test & $* *$ & $* *$ & $* *$ & $* *$ & $* *$ & $* *$ & ns & $*$ & $\mathrm{~ns}$ \\
\hline I - first year, II - second year, III - third year; F test of significance, ns - not significant, * - significant, ** - very significant & &
\end{tabular}

Plant height and number of internodes are different when the field pea is grown as a single crop or in the mixture (Table 3). Even though the differences were not as regular, the results were lowest when field pea is grown in 100:20\% mixtures. Observing the results, it is clear that the field pea share in yield is decreasing when the oat seed rate is increasing. Similar results were recorded in another study (Uzun and Asik, 2012) and are supported by other research (Tan and Serin, 1996).

As shown in table 2, cultivar Kosmaj and Adam had the highest plants and number of internodes. Highest plants for cv. Kosmaj were recorded when the cultivar was cultivated as a single crop, but this wasn't observed precisely for cv. Adam and Letin (Figure 1).

Cultivar Kosmaj had the highest number of internodes (figure 2). These values were highest in the mixture 100:10\%. Results for Adam and Letin weren't regular and this trait wasn't affected by the different seed rates.

For all cultivars, field pea share in yield decreased with the increase of oat in seed rates (figure 3 ).

Interactions between the cultivars and mixtures were not recorded for plant height, number of internodes and field pea share in yield. 
Table 3. Plant height, number of internodes, yield share for single grown crops and two seed rates.

\begin{tabular}{cccccccccc}
\hline Mixture & \multicolumn{3}{c}{ Plant height $(\mathbf{c m})$} & \multicolumn{3}{c}{ Number of internodes } & \multicolumn{3}{c}{ Field pea share in yield (\%) } \\
\hline & I & II & III & I & II & III & I & II & III \\
\hline 100 & 108.9 & $106.9^{\mathrm{a}}$ & $94.7^{\mathrm{b}}$ & $13.44^{\mathrm{a}}$ & 12.44 & $12^{\mathrm{b}}$ & - & - & - \\
$100: 10$ & 108.4 & $98.2^{\mathrm{b}}$ & $99.6^{\mathrm{a}}$ & $12.74^{\mathrm{ab}}$ & 13.1 & $13.2^{\mathrm{a}}$ & $92.8^{\mathrm{a}}$ & 93.3 & $68.8^{\mathrm{a}}$ \\
$100: 20$ & 100.6 & $100.9^{\mathrm{ab}}$ & $92.1^{\mathrm{b}}$ & $12.35^{\mathrm{b}}$ & 13.0 & $12^{\mathrm{b}}$ & $87.1^{\mathrm{b}}$ & 89.0 & $54.3^{\mathrm{b}}$ \\
F test & $\mathrm{ns}$ & $*$ & $*$ & $*$ & $\mathrm{~ns}$ & $* *$ & $*$ & $\mathrm{~ns}$ & $* *$ \\
\hline
\end{tabular}

I - first year, II - second year, III - third year; F test of significance, ns - not significant, * - significant, ** - very significant

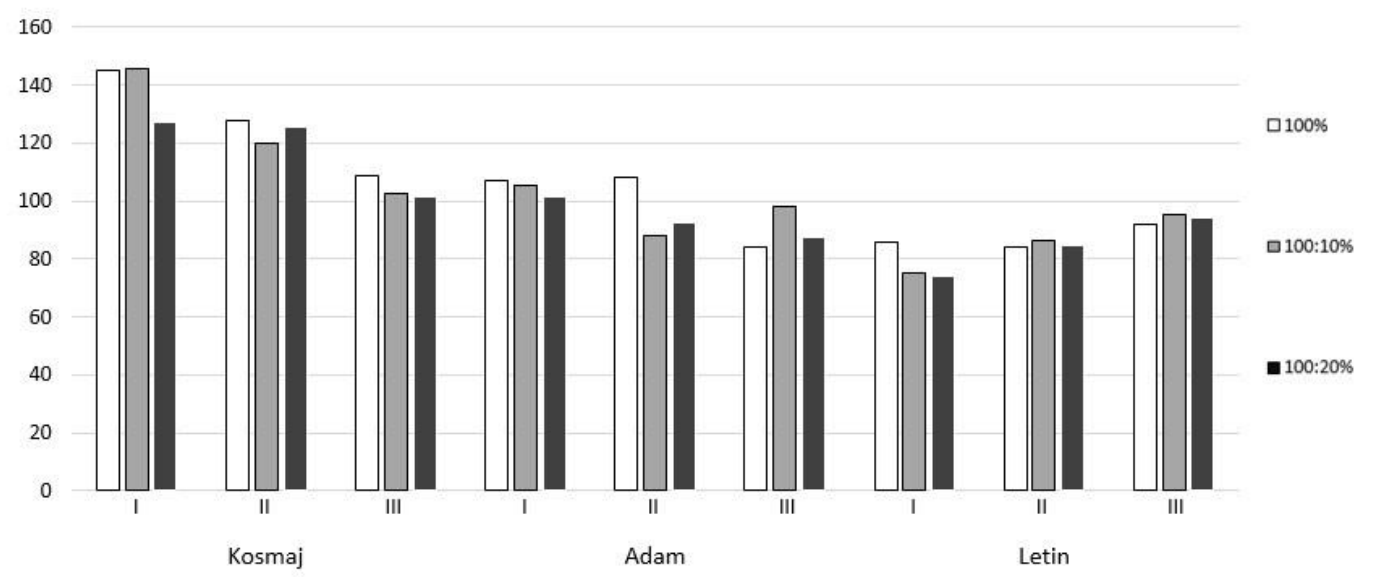

Figure 1. Plant height $(\mathrm{cm})$ for different cultivars and different seed rates, I - first year, II - second year, III - third year.

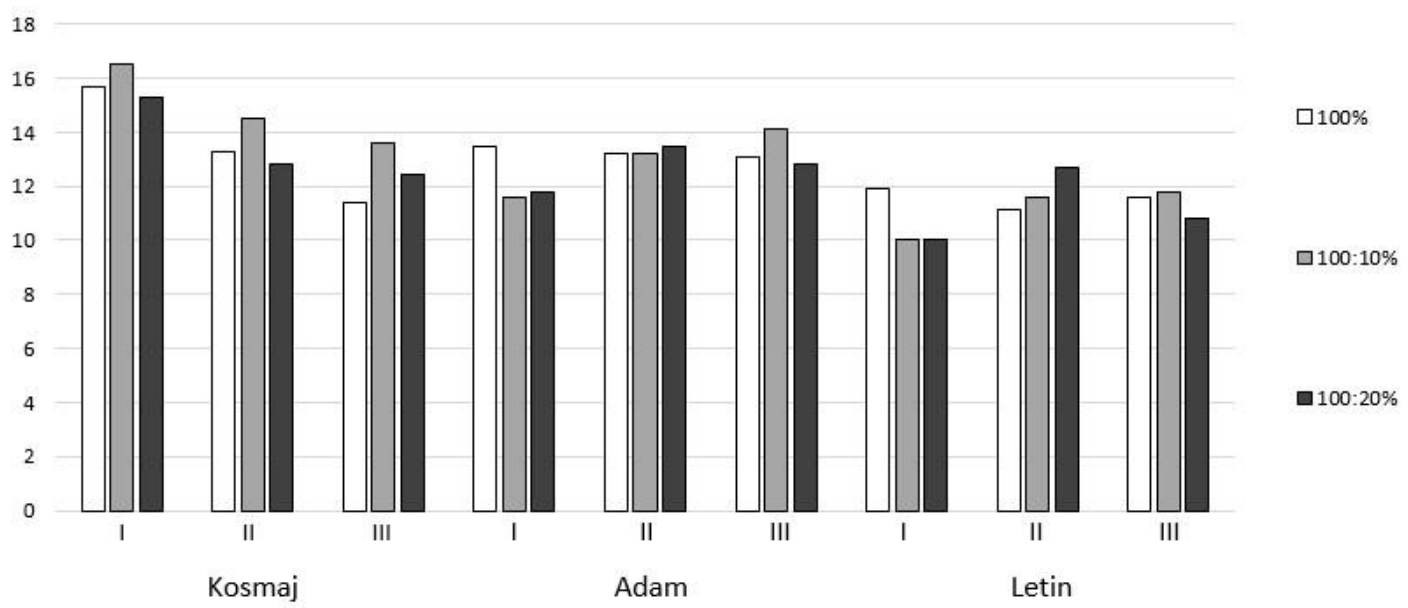

Figure 2. Number of internodes for different cultivars and different seed rates, I - first year, II - second year, III - third year

The highest dry weight yields were observed for cultivar Adam and Kosmaj, and lowest for leafless type cultivar Letin (table 4). In the first year, high yields were also recorded for oat and were equal to that of cultivar Adam and Kosmaj. Fresh weight yield followed the same trend keeping the cultivar Adam and Kosmaj dominant in all three years. Average herbage yield of field pea, grown in dry growing conditions, show similar yields, cv. $16-$ $20.572 \mathrm{t} \mathrm{ha}^{-1}$, cv. 16-K - $28.234 \mathrm{t} \mathrm{ha}^{-1}$, cv. 16-DY $-27.88 \mathrm{t}$ ha $^{-1}$, cv. 16-Z - $21.64 \mathrm{t} \mathrm{ha}^{-1}$, cv. K - $14.93 \mathrm{t} \mathrm{ha}^{-1}$ (Tekeli and Ates, 2003). In another trial (Hungary) yields of two single grown field pea cultivars were $29.68 \mathrm{t} \mathrm{ha}^{-1} \mathrm{cv}$. IP5 and $33.03 \mathrm{t} \mathrm{ha}^{-1} \mathrm{cv}$. Rubin (Hoffman, 2003). When we compare the yields of cv. Kosmaj and Adam we can conclude that most cultivars in the region of Eastern Europe have similar performance in the dry growing conditions. 


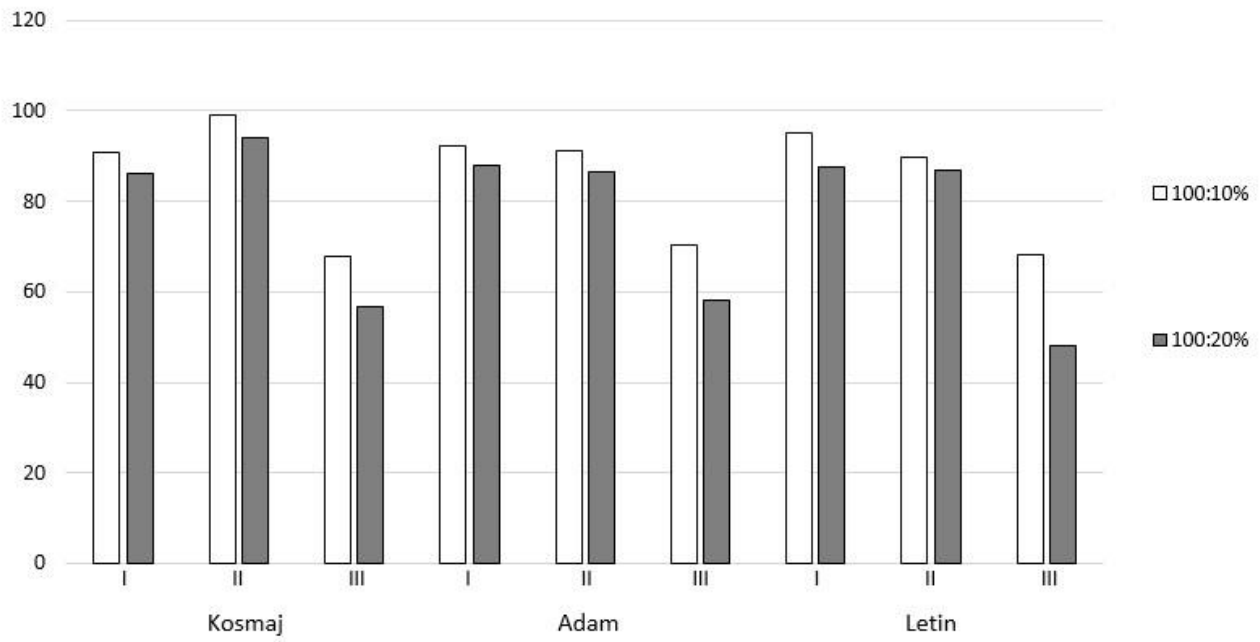

Figure 3. Field pea share in yield (\%) for different cultivars and different seed rates, I - first year, II - second year, III - third year

Table 4. Average yields and crude protein content for field pea cultivars and oat.

\begin{tabular}{|c|c|c|c|c|c|c|c|c|c|}
\hline \multirow[t]{2}{*}{ Cultivar } & \multicolumn{3}{|c|}{ Dry weight $\left(\mathrm{t} \mathrm{ha}^{-1}\right)$} & \multicolumn{3}{|c|}{ Fresh weight $\left(\mathrm{t} \mathrm{ha}^{-1}\right)$} & \multicolumn{3}{|c|}{ Crude proteins $\left(\mathrm{g} \mathrm{kg}^{-1}\right)$} \\
\hline & I & II & III & I & II & III & I & II & III \\
\hline Kosmaj & $4.19^{\mathrm{a}}$ & $4.22^{\mathrm{a}}$ & $3.91^{\mathrm{a}}$ & $26.28^{a}$ & $23.11^{\mathrm{a}}$ & $19.82^{\mathrm{a}}$ & $169.5^{\mathrm{a}}$ & $152.4^{\mathrm{a}}$ & $138^{\mathrm{b}}$ \\
\hline Adam & $4.25^{\mathrm{a}}$ & $3.96^{\mathrm{a}}$ & $2.98^{\mathrm{b}}$ & $29.22^{\mathrm{a}}$ & $21.48^{\mathrm{a}}$ & $14.27^{\mathrm{b}}$ & $176.4^{\mathrm{a}}$ & $153.7^{\mathrm{a}}$ & $161.7^{\mathrm{a}}$ \\
\hline Letin & $1.96^{\mathrm{b}}$ & $2.36^{\mathrm{b}}$ & $2.7^{\mathrm{b}}$ & $11.94^{\mathrm{b}}$ & $11.98^{\mathrm{b}}$ & $12.97^{\mathrm{b}}$ & $157.4^{\mathrm{a}}$ & $118.1^{\mathrm{b}}$ & $132.6^{\mathrm{b}}$ \\
\hline Jadar (oat) & $4.13^{\mathrm{a}}$ & $2.67^{b}$ & $2.62^{b}$ & $24.52^{\mathrm{a}}$ & $12^{\mathrm{b}}$ & $12.42^{\mathrm{b}}$ & $62.2^{\mathrm{b}}$ & $66.6^{c}$ & $82.5^{\mathrm{c}}$ \\
\hline F test & $* *$ & $* *$ & $* *$ & $* *$ & $* *$ & $* *$ & $* *$ & $* *$ & $* *$ \\
\hline
\end{tabular}

I - first year, II - second year, III - third year; F test of significance, ns - not significant, * - significant, ** - very significant

Highest crude protein content was observed for cultivar Adam, followed by cultivar Kosmaj, and then Letin. Crude protein content for field pea and oat mixtures, on molic gleysols and eutric cambisols, in full flowering stage of development were $14.69 \%$ and $14.99 \%$ respectively (Brkić et al., 2004), while some researches have other results 17-18\% (Turk et al., 2011). It has been concluded that the protein content for cultivar Kosmaj and Adam are satisfying given the limited growing condition, while cultivar Letin had lower average protein content. The lowest content was expectedly recorded for oat. Low crude protein content for oat is expected and is observed in another research as well (Carr et al., 2004).
Even though the LER values were different, and were higher in 100:20\% mixture for all 3 years, analysis have shown that these differences were not significant (Table 5). In similar trials, values for index LER are increasing with the increase of field pea in seed rates (field pea:oat, $50: 50 \%$-LER $=0.87 ; 75: 25 \%$-LER $=0.96 ; 85: 15 \%$-LER $=$ 1.2 , on average) (Vasiljević et al., 2016). In another trial, where oat was grown in two different ratios, oat:field pea $-100: 50 \%$ and 50:50\%, LER index was 1.14 and 1.07 respectively (Pelicano et al., 2015). LER values in our trial were either similar or higher compared to these results.

Table 5. LER, dry and fresh weight and crude protein content for single grown crops and two seed rates.

\begin{tabular}{|c|c|c|c|c|c|c|c|c|c|c|c|c|}
\hline \multirow[t]{2}{*}{ Mixture } & \multicolumn{3}{|c|}{ LER } & \multicolumn{3}{|c|}{ Dry weight $\left(\mathrm{t} \mathrm{ha}^{-1}\right)$} & \multicolumn{3}{|c|}{ Fresh weight $\left(\mathrm{t} \mathrm{ha}^{-1}\right)$} & \multicolumn{3}{|c|}{ Crude proteins $\left(\mathrm{g} \mathrm{kg}^{-1}\right)$} \\
\hline & $\mathbf{I}$ & II & III & I & II & III & $\mathbf{I}$ & II & III & I & II & III \\
\hline 100 & - & - & & 3.3 & $2.8^{\mathrm{b}}$ & $2.29^{c}$ & 21.67 & $15.74^{\mathrm{b}}$ & $12.34^{\mathrm{b}}$ & 149.3 & 136.2 & 136.9 \\
\hline 100:10 & 1.05 & 1.12 & 1.41 & 3.51 & $3.66^{\mathrm{a}}$ & $3.14^{\mathrm{b}}$ & 22.39 & $19.15^{\mathrm{a}}$ & $15.76^{\mathrm{ab}}$ & 163.4 & 126.4 & 141 \\
\hline 100:20 & 1.12 & 1.23 & 1.67 & 3.87 & $4.05^{\mathrm{a}}$ & $4.25^{\mathrm{a}}$ & 24.32 & $20.42^{\mathrm{a}}$ & $18.98^{\mathrm{a}}$ & 161.5 & 138.4 & 136.3 \\
\hline $\mathrm{F}$ test & ns & ns & ns & ns & $* *$ & $* *$ & ns & $*$ & $* *$ & ns & ns & ns \\
\hline
\end{tabular}

Dry weight increase was recorded for the second and third year with high significance and was influenced by the increase of oat in seed rates. Dry weight increase was recorded in a previous study for field pea and oat mixtures grown in spring, and it was higher in 100:30 mixture compared to 100:15 mixture (Krga et al., 2016). Same results were recorded in another research (Uzun and Asik, 2012). Fresh weight yield is also increasing with the increase of oat in seed rates, in the second and third year with high significance. Based on these researches it can be said that increase of oat in seed rates will increase overall yields. 
Different seed rates do not affect crude protein content. Average crude protein content for field pea and triticale mixtures, at the dough-milky stage of development of the cereal, is $163 \mathrm{~g} \mathrm{~kg}^{-1}$ (Maxin et al., 2016). In another research average crude protein content of field pea:oat mixture $(75: 25 \%)$, at the dough-milky stage of development of oat is $12.96 \%$ (Uzun and Asik, 2012). Comparing these results, we can conclude that mixtures $100: 10 \%$ and 100:20\% can provide a decent amount of proteins when cultivated in dry growing conditions.
Dry weight yields were highest in 100:20\% mixtures followed by $100: 10 \%$ mixtures (figure 4). Average dry matter yields for other cereal and legume mixtures are $5.44 \mathrm{t} \mathrm{ha}^{-1}$ for grass pea:barley $-75: 25 \%$ and $4.13 \mathrm{t} \mathrm{ha}^{-1}$ for vetch:barley - 75:25\% (Javanmard et al., 2014). Yields for cv. Kosmaj and Adam in mixture with oat are similar to these values, while Letin had lower yields, showing that basic types of field pea (Kosmaj and Adam) can perform as good as other annual legume and cereal mixtures.

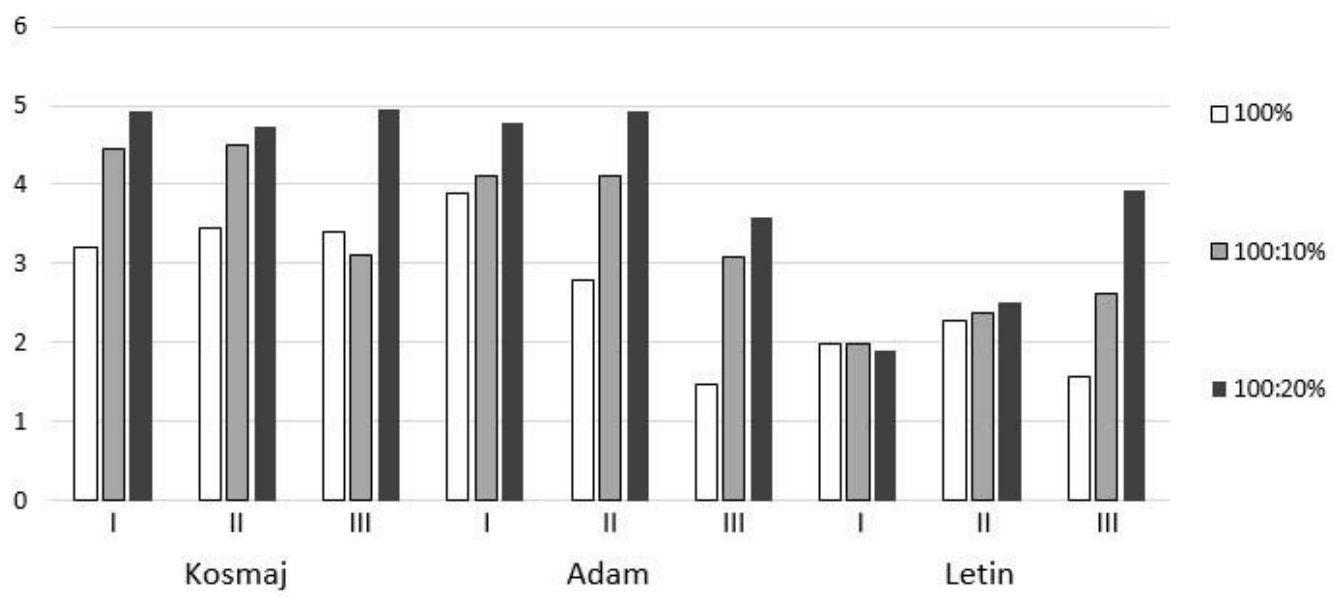

Figure 4. Dry weight yield $\left(\mathrm{t} \mathrm{ha}^{-1}\right)$ for different field pea cultivars and different seed rates; I - first year, II - second year, III - third year

Fresh weight yields followed the similar pattern (figure 5).

Results have shown that there were no significant differences in crude protein content between different seed rates (table 5). The lowest protein content was recorded in mixture $100: 20 \%$ for cultivar Kosmaj, in mixture
100:10\% for cultivar Adam and in mixture 100:10\% and $100: 20 \%$ for cultivar Letin (figure 6). Regarding the crude protein content, each cultivar is performing differently when in the mixture or grown as a single crop. Uzun and Asik (2012) have shown that protein content tends to decrease with the increase of oat in seed rates.

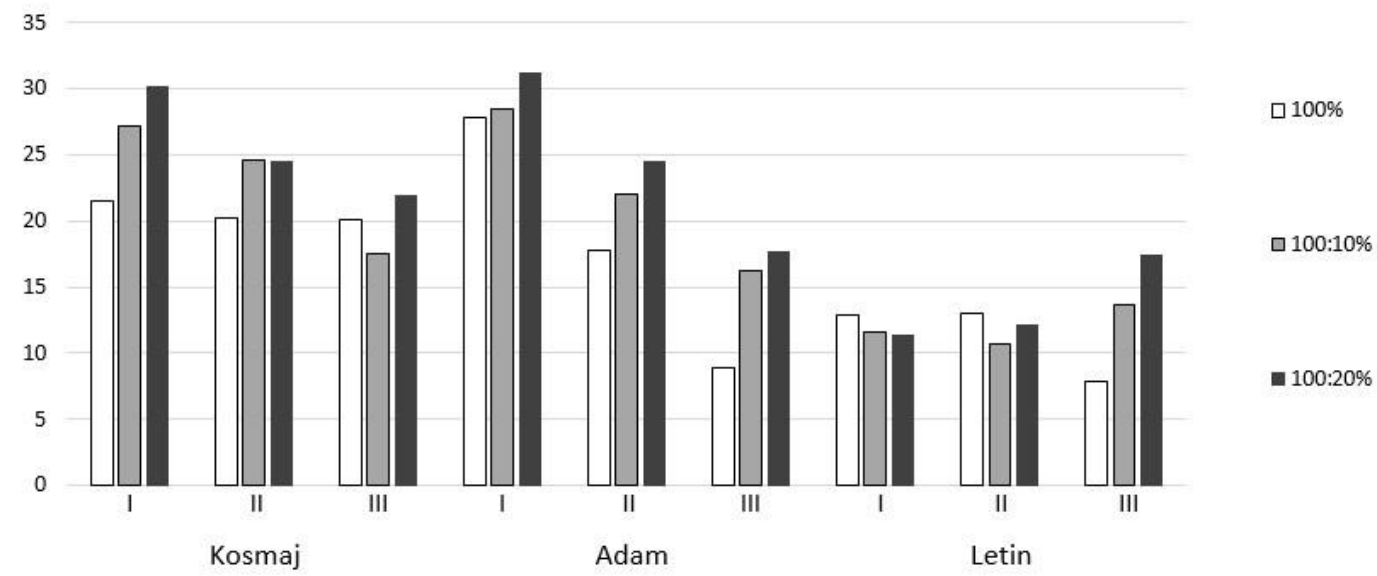

Figure 5. Fresh weight yield $\left(\mathrm{t} \mathrm{ha}^{-1}\right)$ for different field pea cultivars and different seed rates; I - first year, II - second year, III - third year 


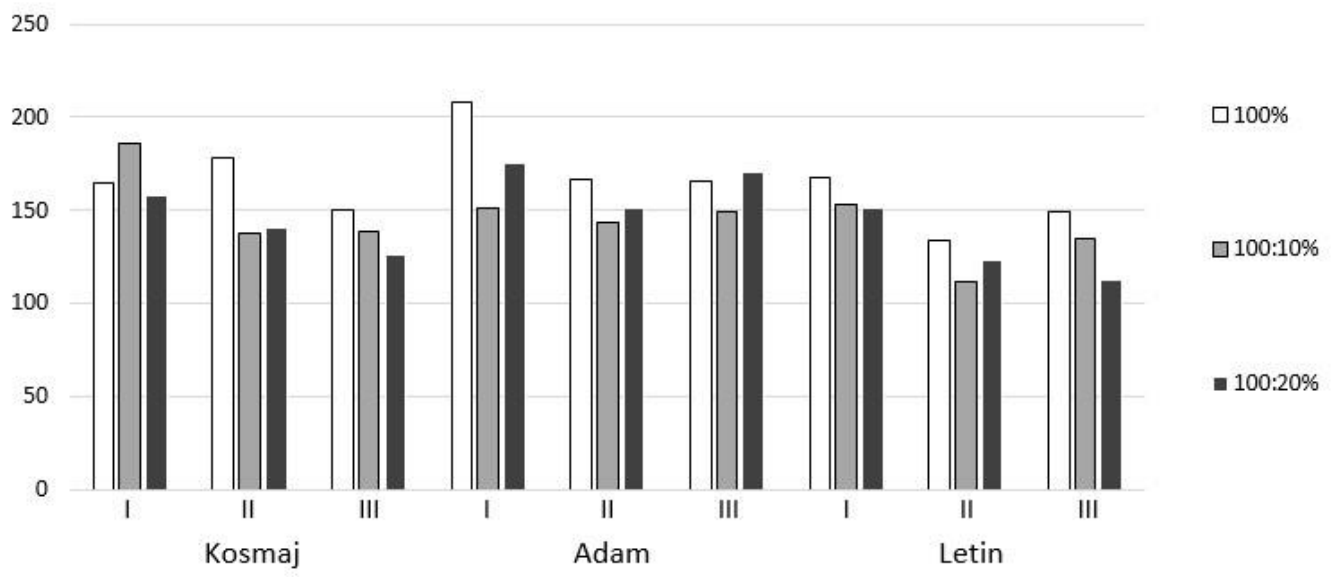

Figure 6. Crude protein content $\left(\mathrm{g} \mathrm{kg}^{-1}\right)$ for different field pea cultivars and different seed rates; I - first year, II - second year, III third year

Combined analysis of variance for 3 years didn't show any significant interactions between the cultivars and mixtures for dry and fresh weight yield, as well as crude protein content.

\section{CONCLUSION}

The potential of field pea and oat intercrops is considered justified for dry growing conditions. This is emphasized for basic type cultivars Kosmaj and Adam. Average yields were different between the cultivars as well as between seed rates. Basic cultivars (Kosmaj and Adam) were generally better developed and had higher dry and fresh weight yields compared to leafless cv. Letin. Highest protein content was recorded for the cultivar Adam, followed by cultivar Kosmaj, and then cultivar Letin. Average yields were increasing when sowing rate of oat was increased in the mixture. Field pea share in yield decreased when oat seed rates increased, but this increase was not affecting the quality of the forage, thus the share of oat in seed rates shouldn't be lower than $20 \%$. LER index increased when the seed rates of oat in the mixture increased. This was observed for Kosmaj x oat in $1^{\text {st }}, 2^{\text {nd }}$ and $3^{\text {rd }}$ year; Adam $x$ oat in $1^{\text {st }}$ and $2^{\text {nd }}$ year, while these changes were not precisely confirmed for the leafless cultivar Letin (LER increased only in the $1^{\text {st }}$ year). Significant interactions between the examined factors were not recorded.

\section{LITERATURE CITED}

AOAC. 2000. Official Methods of Analysis, 17th edn, Arlington, VA, USA: Association of Official Analytical Chemists.

Banik, P., A. Midya, B.K. Sarkar, S.S. Ghose. 2006. Wheat and chickpea intercropping systems in an additive series experiment: advantages and weed smothering. Eur. J. Agron. 24: $325-332$.

Borreani, G., L. Cavallarin, S. Antoniazzi, E. Tabacco. 2006. Effect of stage of growth, wilting and inoculation in field pea (Pisum sativum L.) silages. I. Herbage composition and silage fermentation. J. Sci. Food Agr. 86: 1377-1382.

Bremner, J. M. 1996. Nitrogen-total. In: Methods of soil analysis, Part 3. Chemical methods (Ed. D. L. Sparks), 10851121, SSSA, Madison.
Brkić, S., Z. Milaković, A. Kristek, M. Antunović. 2004. Pea yield and its quality depending on inoculation, nitrogen and molybdenum fertilization. Plant Soil Environ. 50: 39-45.

Carr, M.P., R.D. Horsley and W.W. Poland. 2004. Barley, oat, and cereal-pea mixtures as dryland forages in the northern great plains. Agron. J. 96: 677-684.

Chapagain, T. and A. Riseman. 2014. Barley-pea intercropping: Effects on land productivity, carbon and nitrogen transformations. Field Crop. Res. 166: 18-25.

Chapko, L.B., M.A. Brinkman, K.A. Albrecht. 2013. Oat, oatpea, barley, and barley-pea for forage yield, forage quality, and alfalfa establishment. J. Prod. Agric. 4: 486-491.

Coll, L., A. Cerrudo, R. Rizzalli, J.P. Monzon, F.H. Andrade. 2012. Capture and use of water and radiation in summer intercrops in the south-east Pampas of Argentina. Field Crop. Res. 134: 105-113.

Deveikyte, I., Z. Kadziuliene, L. Sarunaite. 2009. Weed suppressionability of spring cereal crops and peas in pure and mixed stands. Agron. Res. 7: 239-244.

Egner, H., H. Riehm, W.R. Domingo. 1960. Untersuchungen über die chemische Bodenanalyse als Grundlage für die Beurte ilung des Nährstoffzustandes der Böden. II. Chemische Extraktionsmethoden zur Phosphor- und Kaliumbestimmung. Kungliga Lantbrukshögskolans annaler. 26: 199-215.

Gronle, A., H. Böhm, J. Heß. 2014. Effect of intercropping winter peas of differing leaf type and time of flowering on annual weed infestation in deep and shallow ploughed soils and on pea pests. Landbauforsch. Volk. 64: 31-44.

Hauggaard-Nielsen, H., P. Ambus, E.S. Jensen. 2001. Interspecific competition, $\mathrm{N}$ use and interference with weeds in pea-barley intercropping. Field Crop Res. 70: 101-109.

Hauggaard-Nielsen, H., M. Gooding, P. Ambus, G. CorreHellou, Y. Crozat, C. Dahlmann, A. Dibet, P. Fragstein, A. Pristeri, M. Monti, E.S. Jensen. 2009. Pea-barley intercropping for efficient symbiotic N2-fixation, soil $\mathrm{N}$ acquisition and use of other nutrients in European organic cropping systems. Field Crop Res. 113: 64-71.

Henseler, M., I. Piot-Lepetit, E. Ferrari, A.D. Mellado, M. Banse, H. Grethe, C. Parisi, S. Helaine. 2013. On the asynchronous approvals of GM crops: Potential market impacts of a trade disruption of EU soy imports. Food Policy. 41: 166-176.

Hoffman, R., F. Der. 2003. Yield of different green forage crops, in pure stand and in mixtures Part 1: Spring (two roweed), 
barley (Hordeum vulgare L.), pea (Pisum sativum L.) and vetch (Vicia sp. L.). Agric. Conspec. Sci. 68: 275-297.

Javanmard, A., Y. Nasiri, F. Shekari. 2014. Competition and dry matter yield in intercrops of barley and legume for forage. Albanian J. Agri. Sci. 13: 22-32.

Krga, I., A. Simić, Z. Bijelić, V. Mandić, S. Vasiljević, Đ. Karagić, D. Milić. 2016. Interspecies relations and yield of different field pea/oats mixtures. Annals of the University of Craiova - Agricluture, Montanology, Cadastre Sercies. 46: 199-205. Craiova, Romania.

Krizmanić, G., T. Čupić, M. Tucak, S. Popović. 2017. Agronomic value of spring field pea breeding lines and varieties for green forage production (Pisum sativum L.). Poljoprivreda. 23: 17-21.

Li, L., J.H. Sun, F.S. Zhang, X.L. Li, S.C. Yang, Z. Rengel. 2001. Wheat/maize or wheat/soybean strip intercropping. I. Yield advantage and interspecific interaction on nutrients. Field Crops Res. 71: 123-137.

Lithourgidis, A.S., C. Dordas, C.A. Damalas, D.N. Vlachostergios. 2011. Annual intercrops: an alternative pathway for sustainable agriculture. Aust. J. Crop Sci. 5: 396-410.

Maxin, G., D. Andueza, A. Le Morvan, R. Baumont. 2016. Effect of intercropping vetch (Vicia sativa L.), field pea (Pisum sativum L.) and triticale ( $X$ Triticosecale) on drymatter yield, nutritive and ensiling characteristics when harvested at two growth stages. Grass Forage Sci. 72: 4.

Mead, R. and R. Willey. 1980. The Concept of a 'Land Equivalent Ratio' and Advantages in Yields from Intercropping. Exp. Agr. 16: 217-228.

Pelicano, A., M. Romeo, A. Pristeri, G. Preiti, M. Monti. 2015. Cereal-pea intercrops to improve sustainability in bioethanol production. Agron. Sustain. Dev. 35(2): 827-835.

Poggio, S. 2005. Structure of weed communities occurring in monoculture and intercropping of field pea and barley. Agr. Ecosyst. Environ. 109: 48-58.

Prusinski, J. 2016. Overwintering and Yield of Winter Cultivars of Field Pea Assas And White Lupine Orus. Electron. J. Pol. Agric. Univ. 19: p1-17, 17.
Rauber, R., K. Schmidtke, F.H. Kimpel. 2001. The performance of pea (Pisum sativum L.) and its role in determining yield advantages in mixed stands of pea and oat (Avena sativa L.). J. Agron. Crop Sci. 187: 69-144.

Sekamatte, B.M., M.O. Latigo, M.R.A. Smith. 2003. Effects of maize-legume intercrops on termite damage to maize, activity of predatory ants and maize yields in Uganda. Crop Prot. 22: 87-93.

Shereena, J. and N. Salim. 2006. Chilling tolerance in Pisum sativum L. seeds: an ecological adaptation. Asian J. Plant Sci. 5: 1047-1050.

Sukhdev, S.M. 2012. Improving crop yield, N uptake and economic returns by intercropping barley or canola with pea. Agri. Sci. 3: 1023-1033.

Tan, M. and, Y. Serin. 1996. A study on the determination of optimum mixture rates and cutting stage for different vetch+cereal mixtures. Ataturk Univ. J. Fac. Agri. 27: 475489.

Tekeli, A.S., E. Ates. 2003. Yield and its components in field pea (Pisum arvense L.) lines. J. Cent. Eur. Agric. 4: 313-318.

Turk, M., S. Albayrak, O. Yuksel. 2011. Effect of seeding rate on the forage yields and quality in pea cultivars of differing leaf types. Turk. J. Field Crops. 16: 137-141.

Uzun, A., F. Asik. 2012. The effect of mixture rates and cutting stages on some yield and quality characters of pea (Pisum sativum L.) + oats (Avena sativa L.) mixture. Turk. J. Field Crops. 17: 62-66.

Vasiljević, S., D. Milić, Đ, Kragić, V. Mihailović, D. Mikić, D. Živanov, B. Milošević, S, Katanski. 2016. Yield of Forage Pea-Cereal Intercropping Using Three Seed Ratios at Two Maturity Stages. In: Roldán-Ruiz I., J. Baert, D. Reheul. (eds) Breeding in a World of Scarcity. Springer, Cham. 215218.

Živanov, D., R. Jevtić, S. Tančić, S. Vasiljević, S. Maširević. 2014. Control of winter forage pea diseases by pea-oat intercropping under field conditions. Pestic. Phytomed. 29: 131-136. 